\title{
Vstup ČR do EU a pojistný trh ČR
}

\author{
Eva Ducháčková ${ }^{1}$
}

\begin{abstract}
Změny v souvislosti se vstupem České republiky do Evropské unie se dotýkají mnoha ekonomických oblastí a samozřejmě i oblasti pojištovnictví. Základní obecné principy uplatňované v rámci EU, tzn. volný pohyb zboží a služeb, kapitálu a osob, mají svůj odraz rovněž ve sféře pojištovnictví, zejména otázka volného pohybu služeb a kapitálu. Změny $\mathrm{v}$ českém pojištovnictví spojené s přistoupením českého pojištovnictví $\mathrm{k}$ jednotnému evropskému pojistnému trhu lze analyzovat z několika pohledů, a to z pohledu legislativního prostředí v rámci pojištovnictví, z hlediska role komerčního pojištění v ekonomice a z pohledu přístupu obyvatelstva a podnikatelských subjektů k pojištění, z pohledu struktury pojistitelů a pojistných produktů na českém pojistném trhu ve srovnání s pojistným trhem Evropské unie.
\end{abstract}

Jednotný evropský pojistný trh, kterého se Česká republika stala členem, funguje na základě tzv. jednotného pasu, tzn. každá pojištovna, která má řádné povolení provozovat pojištovacíčinnost v některé z členských zemí Evropské unie, může při splnění určitých minimálních požadavků (oznamovací povinnost vưči odpočívajícímu dozorovému orgánu) rozšíriit své aktivity i do jiných členských států, a to budformou zřízení pobočky nebo poskytováním pojištění na základě svobody dočasného poskytování služeb přímo ze svého domovského státu. Státní dozor vykonává dozorčí orgán v zemi, kde má pojištovna sídlo. Tzn. zahraniční pojištovnase sídlem v některé z členských zemí Evropské unie může provozovat pojištění v Ćeské republice pouze pod státním dozorem v domovském zemi dané pojištovny. Z toho ovšem také vyplývá, že pojištovny se sídlem v ČR mohou provozovat pojištění v ostatních členských zemích Evropské Unie pod dohledem státního dozoru nad pojištovnictvím v České republice (dnes Ministerstva financí ČR).

\section{Legislativní oblast}

Z výše charakterizovaného principu jednotného pasu vyplývá, že v souvislosti se vstupem České republiky do Evropské unie bylo nutno legislativně upravit tuto významnou změnu v postavení pojistitelů. Před 1 . květnem 2004 byl český pojistný trh prakticky uzavřený, tzn. na pojistném trhu mohli působit pouze pojistitelé, kteří k provozování pojištovací činnosti obdrželi povolení od Ministerstva financí CR, a současně pojistitelé, kteří toto povolení od Ministerstva financí k provozování pojištovacíčinnosti v podmínkách České republiky obdrželi, neměli možnost působit na pojistném trhu Evropské unie aniž by zde rovněž obdrželi povolení k provozování pojištovací činnosti. Proto hlavní otázkou v rámci novelizace Zákona o pojištovnictví, platné právě od 1.5.2004, bylo uzákonění této podstatné změny.

Obecně jsou na první pohled nejznatelnější změny v pojištovnictvív posledním období patrné právě v legislativní oblasti. Řada těchto legislativních změn je vázána sice na vstup České republiky do Evropské unie, ovšem je třeba si uvědomit, že zpracování některých

1 Doc. Ing. Eva Ducháčková, CSc., Katedra bankovnictví a pojištovnictví Fakulty financí a účetnictví Vysoké školy ekonomické v Praze. 
nových pojištovacích právních předpisů souvisí s vývojem a potřebami vyvíjejícího se pojistného trhu. Legislativní změny v pojištovnictví lze charakterizovat jako dlouhodobé. Vlastně již od roku 1991 docházelo postupně ke schválení celé řady významných pojištovacích právních norem, ale i právních norem, které zprostředkovaně působí na pojištovací činnost. $\mathrm{V}$ průběhu devadesátých let legislativní změny souvisely s požadavky pojistného trhu na základě postupného přizpůsobování se českého pojištovnictví tržním principům a obvyklým podmínkám na pojistných trzích.

$\mathrm{V}$ posledních letech docházelo $\mathrm{k}$ harmonizaci českého pojistného práva s právem Evropské unie, a to zejména od roku 2000. Zde lze pozorovat zejména soustředění se v oblasti regulace pojištoven na finanční zdraví pojištoven a kontrolu managementu pojištoven. Harmonizace pojistného práva byla ve velké míre ovšem dovršena na počátku roku 2004, kdy vyšla ve sbírce zákonů novelizace zákona o pojištovnictvís platností od 1. 5. 2004, resp. 1. 4. 2004, zákon o pojistné smlouvě s platností od 1.1. 2005 (některá ustanovení jsou platná již od 1. 5. 2004), zákon o pojištovacích zprostředkovatelích a samostatných likvidátorech pojistných událostí s platností od 1.1.2005, novelizace zákona o pojištění odpovědnosti za škody z provozu vozidel s platností od 1.5.2004 a další legislativní změny, které se pojištovací činnosti dotýkají (např́íklad daňové zákony).

Novelizace Zákona o pojištovnictvívedle uzákonění jednotného pasu pro činnost pojištoven znamená i další změny pro fungování a činnost pojištoven, zejména z pohledu jejich regulace. Na jedné straně došlo ke zpřísnění pravidel pro tvorbu technických rezerv, rozšíření jejich informačních povinností a posílení pravomocí orgánu státního dozoru, na druhé straně širší možnosti investování. Tato opatření měla za cíl kromě jiného zvýšení bezpečnosti činnosti pojistitelů z pohledu klientů pojištoven. Současně si je třeba uvědomit, že zvýšení bezpečnosti bude zřejmě spojeno s určitým vzrůstem nákladů na tvorbu technických rezerv, navýšení nákladů na vnitřní kontrolní systém a administrativu spojenou s výkaznictvím.

Zákon o pojištovnictví samozřejmě upravuje také pravomoci a povinnosti orgánu státního dozoru v pojištovnictví. Státní dozor v pojištovnictví je v současné době vykonáván v rámci Ministerstva financí. Do budoucna, i v návaznosti na př́stupy v zemích Evropské unie, se počítá s postupným vytvořením jednotného finančního dozoru, jehož součástí bude i orgán státního dozoru nad pojištovnictvím, vedle dohledu nad bankami, spořitelními a úvěrovými družstvy, dohledu nad kapitálovým trhem a dozoru v penzijním připojištění.

Změny souvisící se schválením nového Zákona o pojistné smlouvě jsou spojeny s nejen se vstupem České republiky do Evropské unie, ale vyplynuly z potřeb, které se dlouhodobě se projevovaly na českém pojistném trhu a byly vyvolány právní úpravou pojistné smlouvy, která neodpovídala změněným podmínkám na pojistném trhu v souvislosti se stále důslednějším uplatňováním tržních principů. Zákonem o pojistné smlouvě dochází k zařazení problematiky základních pojistných vztahů, tzn. vztahů mezi pojištovnou a jejím klientem, do samostatného zákona. $V$ předchozím dlouhém období byla úprava této problematiky obsažena v rámci Občanského zákoníku. Přínos nové právní úpravy pojistné smlouvy je třeba vidět vedle jasného vymezení obsahu, vzniku a zániku pojistné smlouvy v definování základních pojmů, které sice jsou využivány pojiš̌tovnamiřadu let, ale ne vždy ve stejných souvislostech a ve stejném kontextu. Takovéto vymezení je samozřejmě v zájmu klientů pojištoven, a to zejména z pohledu jejich snažší orientace při sjednávání pojistných produktů. Nová je také úprava a vymezení pojištění škodových a obnosových. Členění pojištěnína pojištění škodová a obnosová představuje členění z pohledu rozdílných principů fungování pojištění, určení velikosti pojistných plnění a nároků klientů na pojistná plnění. Kromě tohoto $\mathrm{z}$ pohledu provozu důležitého vymezení podob pojištění, které 
nahradilo ve staré právní úpravě členění pojištění na pojištění majetku, pojištění osob a pojištění odpovědnosti za škody, Zákon o pojistné smlouvě dále specifikuje zvláštnosti jednotlivých pojistných odvětví a specifických druhů pojištění. Z pohledu klientů pojištovenje jistě důležité v rámci Zákona o pojistné smlouvě stanovení pevné tříměsíční lhůty od nahlášení pojistné události, ve které musí pojištovny vyplatit pojistné plnění (dosud škoda musela být proplacena do jednoho měsíce od ukončení šetření případu, přičemž nebylo uvedeno, jak dlouho může šetření př́ípadu probíhat). Úprava v rámci tohoto zákona dále vymezuje informační povinnost pojištoven vůči klient, a to co se týče obsahu pojistné smlouvy, zejména rozsahu pojistného krytí a právech pojištěného.

Nový Zákon o pojištovacích zprostředkovatelích a samostatných likvidátorech znamená přesnější vymezení postavení těchto specificky zaměřených podnikatelských subjektů na pojistném trhu. Pro činnosti těchto subjektů znamená zvýšení nároků na jejich činnost, nebot̉ ukládá splnění předpokladů v oblasti odborné způsobilosti, v otázkách finanční způsobilosti (zvýšení limitů u povinného pojištění odpovědnosti za škody, vymezení požadavků na finanční vybavení) a splnění požadavků na důvěryhodnost osob danou činnost vykonávajících.

Novela zákona o pojištění odpovědnosti za škody z provozu vozidel zejména znamená přizpůsobení podoby tohoto pojistného produktu podmínkám uplatňovaným v Evropské unii. Jde o pojištění s velkým významem z pohledu krytí škod při dopravním provozu a o pojištění, které je typické striktní regulací ze strany států. A to zejména z pohledu přesného vymezení podoby pojištění, tedy vymezení druhů pojistných plnění a podmínek nároků na pojistná plnění, limitů pojistných plnění apod., a dále z pohledu regulace provozu pojištění ze strany státu. Proto podoba tohoto povinného pojištění se přizpůsobila postupně podmínkám uplatňovaným v Evropské unii. Nový zákon přizpůsobuje velikost limitů pojistných plnění, tedy zvyšuje limit plnění u škod na zdraví z dřívějších 18 mil. Kč na dnešních 35 mil. Kč na jednoho poškozeného při dopravních nehodě a u škod na majetku $z$ dřívějších 5 mil. Kč na dnešních 18 mil. Kč na jednu pojistnou událost (limity v Evropské unii dnes platí ve výši 1 mil. EUR u škod na zdraví a 500 tis. EUR u škod na majetku). Dále kromě jiného nová úprava pojištění odpovědnosti za škody z provozu vozidel zavádí instituci škodního zástupce jednotlivých pojistitelů pro vyřizování škodních událostí v zahraničí.

Dlouhou dobu se dále očekává legislativní změna týkající se pravidel a podoby odškodňování pracovních úrazů a nemocí z povolání. Dnešní zákonná podoba znamená, že ve své podstatě nejde v pravém slova smyslu o pojištění, i kdyžje uskutečňováno vybranými dvěma komerčními pojištovnami. Jedná se pouze o zakázku, kterou tyto pojištovny vykonávají pro stát, což je podtrženo skutečností, že finanční výsledky tohoto pojištění jsou vyrovnávány se státním rozpočtem. V podstatě již od zavedení současné zákonné podoby odpovědnostního pojištění, které je na krytí pracovních úrazů a nemocí z povolání zaměřeno, se ukazuje snaha podobu krytí důsledkủ pracovních úrazů a nemocí z povolání přizpůsobit tržním podmínkám, tedy změnit základní koncepci a konstrukci tohoto pojištění tak, aby odpovídala tržním principům, nebo přesunout krytí důsledků pracovních úrazů a nemocí z povolání mimo oblast komerčního pojištění, tedy přesunout ho do oblasti sociálního pojišstění. To, že se se zákonnou podobou pojišstění, která je dnes uplatněna v souvislosti s krytím dopadů pracovních úrazů a nemocí z povolání, již do budoucna výrazněji nepočítá, vyplývá i ze skutečnosti, že zákonná podoba pojištění není zahrnuta v novém Zákoně o pojistné smlouvě. To znamená, že otázka odškodňování pracovních úrazů a nemocí z povolání čeká na řešení v blízké budoucnosti, a to i v návaznosti na vstup České republiky do Evropské unie. 


\section{Role komerčního pojišstění v ekonomice}

Role komerčního pojištěnív ekonomice je obvykle měřena pomocí ukazatelů pojištěnosti. K nejvíce vypovídajícím ukazatelům se řadí ukazatel poměřující výši předepsaného pojistného s velikostí hrubého domácího produktu. V zemích Evropské unie v posledním období celková hodnota tohoto ukazatele přesahuje $9 \%$, přitom předepsané pojistné ve vztahu k HDP u životního pojištění přesahuje výši 5,5 \% a v neživotním pojištění se blíží výši 3,5\%. V České republice dosahuje hodnota globální pojištěnosti výše $4 \%$ (u životního pojištění $1,5 \%$ a u neživotního pojištění $2,5 \%$ ). Pojišsěnost v České republice je ve srovnání se situací v Evropské unii výrazně nižší (viz graf č. 1 a č. 2). Ovšem je třeba se podívat na vývoj v pojištěnosti od počátku devadesátých let, který ukazuje na rychlý růst. Od roku 1992 se hodnota ukazatele pojištěnosti zdvojnásobila (viz graf č. 2), z čehož lze usuzovat, že význam pojištovnictvív podmínkách České republiky se zvyšuje. Zvyšuje se v návaznosti na vzrůstající odpovědnost jednotlivých ekonomických subjektů za krytí rizik, která je ohrožují. Toto vyplývá jednak z prohlubování tržních podmínek ve všech oblastech činnosti a života lidí v souvislosti s omezování role státu při krytí rizik, jednak z uvědomění si existence rizik a potřeb reakce na jejich existenci.

\section{Graf č. 1: Podíl předepsaného pojistného na HDP v EU v \%}

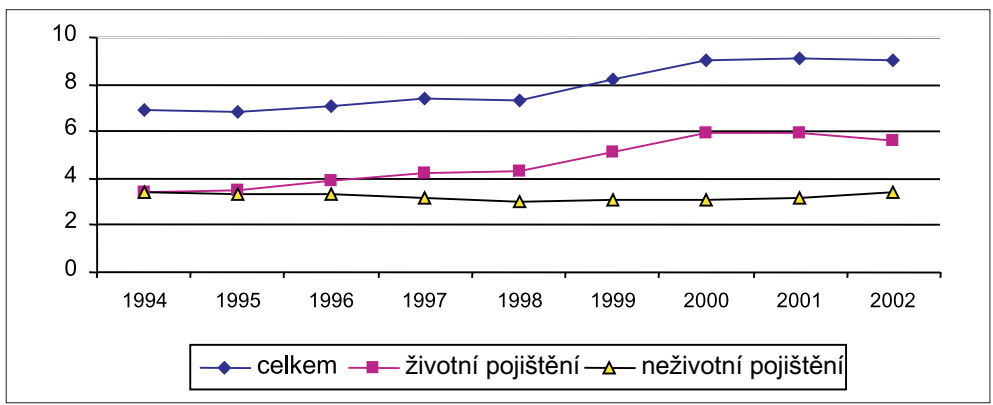

Pramen: World insurance in 2002: high premium growth in non-life insurance, Sigma No. 8/2003, Economics Research \& Consulting, Swiss Reinsurance Company, Zürich.

Graf č. 2: Podíl předepsaného pojistného na HDP v ČR v \%

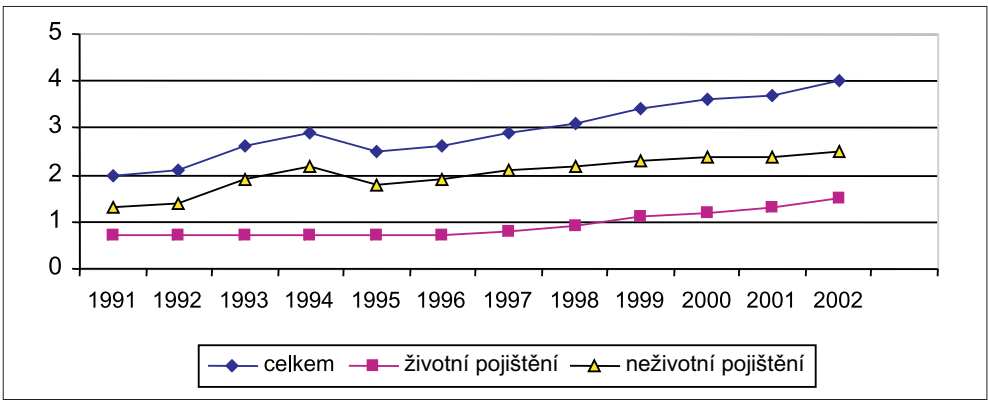

Pramen: Výroční zprávy České asociace pojištoven.

Vedle ukazatele pojištěnosti vycházejícího z poměru předepsaného pojistného a hrubého domácího produktu se pro hodnocení míry pojišsěnosti použivá dále ukazatele pře- 
depsané pojistné na jednoho obyvatele. I při sledování hodnot tohoto ukazatele jsou patrné rozdíly v České republice a Evropské unii (viz tabulka č. 1).

Tab. č. 1: Velikost pojistného na jednoho obyvatele v USD v roce 2002

\begin{tabular}{|l|c|c|c|}
\hline & \multicolumn{3}{|c|}{ předepsané pojistné na jednoho obyvatele v USD } \\
\hline Země EU celkem & celkem & životní pojištění & neživotní pojištění \\
\hline - Velká Británie & $\mathbf{1 9 8 1 , 2}$ & $\mathbf{1 2 0 7 , 9}$ & $\mathbf{7 7 3 , 3}$ \\
\hline - Irsko & 3879,1 & 2679,4 & 1199,7 \\
\hline - Dánsko & 2703,0 & 1712,2 & 990,7 \\
\hline - Nizozemsko & 2448,3 & 1574,9 & 873,4 \\
\hline - Finsko & 2472,4 & 1296,1 & 1176,3 \\
\hline - Francie & 2272,1 & 1765,3 & 506,8 \\
\hline - Belgie & 2064,2 & 1349,5 & 714,7 \\
\hline - Lucembursko & 2002,9 & 1323,6 & 679,3 \\
\hline - Švédsko & 1934,3 & 840,0 & 1094,3 \\
\hline - Německo & 1792,7 & 1232,2 & 560,5 \\
\hline - Rakousko & 1627,7 & 736,7 & 891,1 \\
\hline - Itálie & 1452,1 & 648,7 & 803,4 \\
\hline - Španělsko & 1435,4 & 904,9 & 530,5 \\
\hline - Portugalsko & 1091,5 & 588,0 & 503,5 \\
\hline - Řecko & 799,4 & 418,6 & 380,8 \\
\hline Česká republika & 253,1 & 116,0 & 137,2 \\
\hline
\end{tabular}

Pramen: World insurance in 2002: high premium growth in non-life insurance, Sigma No. 8/2003, Economics Research \& Consulting, Swiss Reinsurance Company, Zürich.

Současně je třeba podotknout, že srovnání hodnot ukazatelů pojištěnosti v České republice a v dalších nových členských zemích Evropské unie ukazuje na skutečnost, že v rámci těchto zemí Česká republika patří z hlediska pojištěnosti k nejvyspělejším (viz tabulka č. 2).

Tab. č. 2: Pojištěnost v nových členských zemích Evropské unie v roce 2002

\begin{tabular}{|l|c|c|}
\hline & $\begin{array}{c}\text { Podíl předepsaného pojistného } \\
\text { na HDP v \% }\end{array}$ & $\begin{array}{c}\text { Předepsané pojistné na } \\
\text { jednoho obyvatele v USD }\end{array}$ \\
\hline Kypr & 4,57 & 603,9 \\
\hline Slovinsko & 5,05 & 557,0 \\
\hline Malta & 4,66 & 457,7 \\
\hline Česká republika & 3,99 & 272,6 \\
\hline Mad'arsko & 2,88 & 186,9 \\
\hline Slovensko & 3,38 & 148,8 \\
\hline Polsko & 2,96 & 144,5 \\
\hline Lotyšsko & 1,91 & 68,5 \\
\hline Litva & 1,46 & 57,9 \\
\hline Estonsko & 1,69 & 63,9 \\
\hline
\end{tabular}

Pramen: World insurance in 2002: high premium growth in non-life insurance, Sigma No. 8/2003, Economics Research \& Consulting, Swiss Reinsurance Company, Zürich. 
V posledním krátkém období je vývoj v pojištovnictví z celosvětového pohledu, tzn. i v Evropské unii, je determinován řadou specifických faktorů. Patří k nim zejména vývoj ve škodovosti, především výskyt pojistných událostí katastrofického rozsahu, výskyt pojistných událostí a rizik, která nebyla v předchozích obdobích obvyklá, a také změny na finančních trzích. Tyto skutečnosti se projevují ve struktuře pojistných trhů, ale také ve změnách $\mathrm{v}$ př́stupu pojistitelů ke krytí rizik, tedy přehodnocování pojistitelnosti rizik, která byla v předchozích obdobích bez větších problémů považována za pojistitelná, změny v přístupech ke konstrukci pojistných produktů a také změny při ohodnocování rizik a stanovení cen pojistných produktů. Nelze opomenout, že výše uvedené faktory se projevují ještě výrazněji na trzích zajistných, což opět v konečném důsledku dopadá na pojistitele.

Růst předepsaného pojistného v Evropské unii v roce 2002 proti roku 2001 představoval celkově $10,7 \%$, z toho u životního pojištění $8 \%$ a v neživotním pojištění $15,1 \%$. V České republice v roce 2002 vzrostlo předepsané pojistné celkem o $13 \%$, přitom předepsané pojistné $\mathrm{v}$ životním pojištění vzrostlo o $21 \%$ a v neživotním pojištění o 8,6 \%. V roce 2003 se celkově předepsané pojistné na českém pojistném trhu zvýšilo o $17,3 \%$, v životním pojištění o $20,6 \%$ a v neživotním pojištění o $15,3 \%$. Růst neživotního pojištění byl v roce 2003 (částečně již v roce 2002) velkou měrou ovlivněn růstem pojistných sazeb v souvislosti s přizpůsobováním se pojištoven novým podmínkách ve škodovosti (po povodních v roce 2002) a novým př́istupům ze strany zajištoven při přebírání zejména majetkových rizik do zajištění. Růst sazeb pojistného v evropských zemích ovlivnil hodnotu růstu předepsaného pojistného v neživotním pojištění již v roce 2002.

Otázkou spojenou se vstupem České republiky do Evropské unie v rámci pojišłovnictví je také problematika př́padných změn cen pojistných produktů. Výše pojistného obecně závisí, vedle výše správních nákladů pojištovny (jejich velikost může být ovlivněna kromě jiného i např́íklad požadavky ze strany státu na tvorbu rezerv a vnitřní kontrolní systémy v pojištovnách), hlavně na četnosti pojistných událostí a velikosti pojistných plnění vyplaceného v souvislosti s jednotlivými pojistnými událostmi. Tedy vychází ze škodovosti, která je ovlivněna v jednotlivých pojistných produktech výskytem škod, ale také se vychází z velikosti sjednaných pojistných částek, dále je cena ovlivněna výskytem hromadných škod (povodně), úrovní a vývojem spotřebitelských cen. Na druhé straně jsou ceny pojistných produktů determinovány konkurencí na pojistném trhu. Pokud v současné době dochází ke zvyšování cen pojistných produktů, není to přímo otázka př́ístupu českého pojištovnictví k jednotnému evropskému pojistnému trhu, ale je to ovlivněno měnícími se podmínkami ve škodovosti, ve spotřebitelských cenách, případně daňovými změnami, změnami ve výši technické úrokové míry (která je upravována v závislosti na vývoji na finančních trzích) atd. a také předchozím vývojem. Vedle toho v současné době se ukazuje vliv podoby zajištění a ceny zajištění na ceny pojistných produktů. Zajištovny totiž reagují na situaci ve škodovosti a ve výskytu katastrofických událostí v posledním období (nárůst globálních rizik), proto mění př́istup k zajištování a zvyšují požadavky na výši zajistného.

Problematika navyšování cen je aktuálnív posledním krátkém období zejména v rámci pojištění podnikatelských rizik. V druhé polovině devadesátých let byly nízké ceny v této oblasti pojištění vyvolány silným konkurenčním bojem na trhu. Např́íklad u živelního pojištění se sazby v průběhu let 1996 až 2001 snížily v některých případech až o 50 \%. Proto také velikost předepsaného pojistného v rámci pojištění majetku podnikatelů stagnovala (v roce 1999 představovalo předepsané pojistné 7,4 mld. Kč, v roce 2001 7,1 mld. Kč). Proto $\mathrm{v}$ posledním období dochází $\mathrm{v}$ tomto segmentu trhu $\mathrm{k}$ výraznému nárůstu cen v souvislosti s přizpůsobováním cen právě změněným podmínkách ve velikosti pojistných plnění, a to především v rámci pojišstění středních a velkých podniků. 
S určitým zvyšováním cen lze počítat v oblasti pojištění odpovědnosti za škody, nebot v evropských podmínkách velikost pojistných plnění, zejména v případě škod na zdraví (bolestné, ztráta společenského uplatnění), je obvykle vyšší. K určitým změnám v této oblasti již v podmínkách České republiky došlo v roce 2002, kdy byla zvýšena hodnota bodu pro ocenění poškození zdraví.

K odůvodněnému zvýšení cen dochází v rámci povinně smluvního pojištění odpovědnosti za škody z provozu vozidla, kde zvýšení ceny je důsledkem navýšení minimálních limitů v rámci provedené legislativní změny v tomto pojištění.

\section{Struktura pojistitelů na pojistném trhu}

Vývoj v počtu a struktuře pojistitelů na českém pojistném trhu je odlišný od vývoje v Evropské unii. Odlišný vývoj v podmínkách České republiky vyplýval z jiných podmínek v pojištovnictví na počátku devadesátých let (přechod od fungování jedné monopolní pojištovny na trhu ke strukturovanému pojistnému trhu). Tento odlišný vývoj se projevoval na jedné straně ve vývoji v počtu subjektů působících na trhu (v podmínkách ČR rostoucí počet pojištoven, $v$ EU určitá míra koncentrace na pojistném trhu od roku 1997) a na druhé straně ve struktuře pojistného trhu z pohledu pojistitelů. V zemích Evropské unie je typické, že trh je z velké části ovládán několika silnými pojistiteli, další pojistitelé hrají doplňkovou roli z hlediska objemu pojistných obchodů (nemusí to tak být z hlediska významu při krytí specifických druhů rizik). K tomuto modelu se pojištovnictvív České republice postupně vyvijíi, i když je zde stále zřetelné významné postavení jedné pojištovny, která je nástupkyní monopolní státní pojištovny z období před rokem 1991 (viz tabulka č. 3).

Graf č. 3: Vývoj počtu pojišštoven v zemích Evropské unie

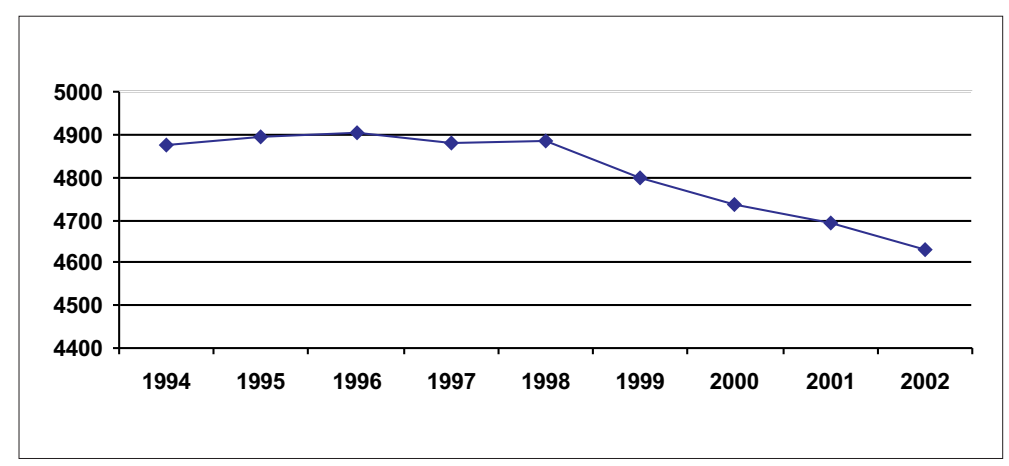

Pramen: CEA: European Insurance in Figures, 2002. 
Graf č. 4: Vývoj počtu pojištoven v České republice

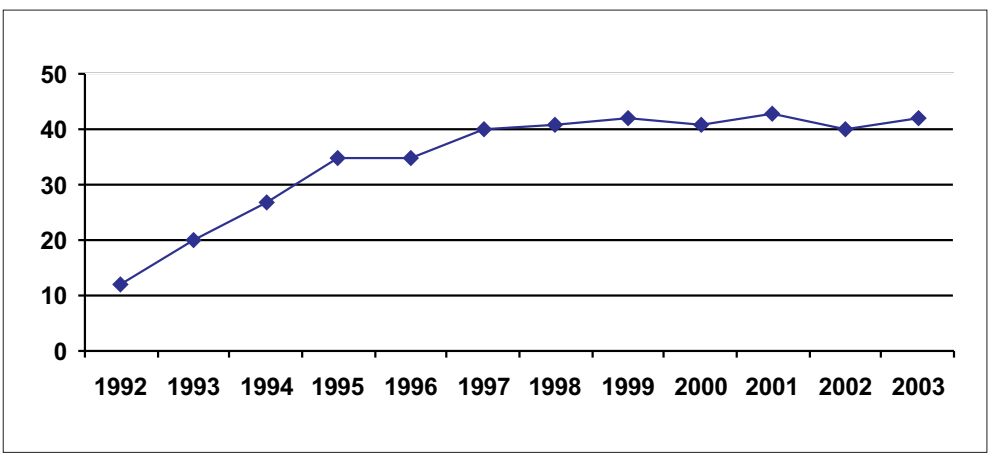

Pramen: Výroční zprávy Úřadu státního dozoru v pojištovnictví a penzijním připojištění, MF ČR.

Tab. č. 3: Struktura pojistitelů na pojistném trhu ČR v \%

\begin{tabular}{|l|c|c|c|c|c|c|c|}
\hline & $\mathbf{1 9 9 3}$ & $\mathbf{1 9 9 5}$ & $\mathbf{1 9 9 7}$ & $\mathbf{1 9 9 9}$ & $\mathbf{2 0 0 0}$ & $\mathbf{2 0 0 1}$ & $\mathbf{2 0 0 2}$ \\
\hline Podíl největší pojištovny & 87,15 & 69,64 & 59,94 & 52,43 & 38,12 & 38,44 & 36,63 \\
\hline Podíl 5 největších pojištoven & 98,33 & 90,50 & 83,66 & 84,62 & 78,38 & 76,34 & 76,12 \\
\hline Podíl 10 největších pojištoven & 99,44 & 97,49 & 95,00 & 94,36 & 91,33 & 90,42 & 91,27 \\
\hline
\end{tabular}

Pramen: Výroční zprávy Úřadu státního dozoru v pojištovnictví a penzijním připojištění, MF ČR.

\section{Struktura pojistných produktů na pojistném trhu}

Od roku 1991, kdy se datuje vznik pojistného trhu v České republice, dochází k postupnému vývoji ve struktuře pojistných produktů ve směru přibližování se struktuře pojistných produktů podmínkám v zahraniční, zejména v Evropě. Zejména se jedná o vývoj v poměru mezi životním a neživotním pojištěním. Z celosvětového pohledu v současné době převažuje životní pojištění. Konkrétně životní dosahuje na celkovém předepsaném pojistném 60\% podíl. V zemích Evropské unie je převaha životního pojištění ještě výraznější.

Graf č. 5: Vývoj podílu předepsaného pojistného v životním a v neživotním pojištění v zemích EU v \%

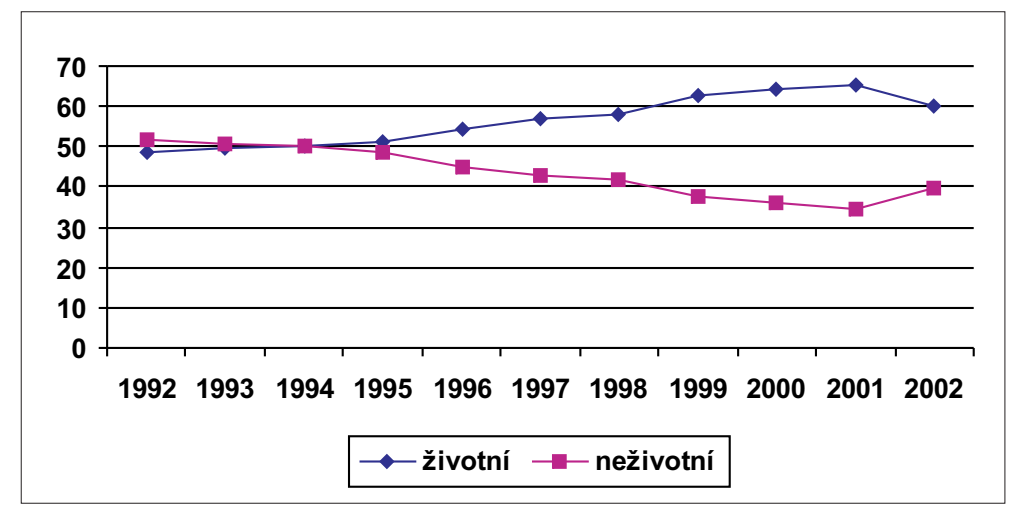

Pramen: CEA: European Insurance in Figures, 2002. 


\section{Graf č. 6: Vývoj podílu životního a neživotního pojištění (podíl předepsaného pojistného)}

v ČR v \%

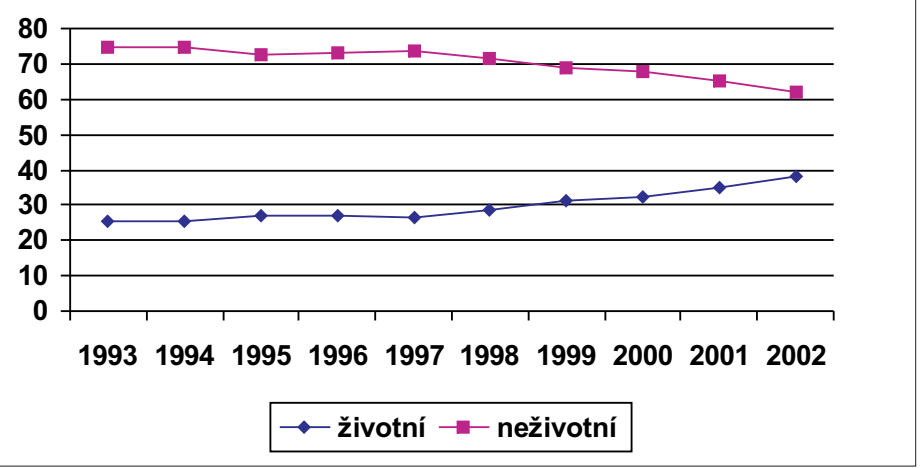

Pramen: Výroční zprávy České asociace pojištoven.

V posledních třech letech $\mathrm{v}$ životním pojištění na českém pojistném trhu je zaznamenáván růst $v$ průměru $20 \%$ ročně, přitom meziroční růst $\mathrm{v}$ zemích Evropské unie zaznamenává podstatně nižší hodnoty. V roce 2001 vzrostlo předepsané pojistné v životním pojištění pouze o $1,2 \%$. Důsledkem rychlého růstu předepsaného pojistného v životním pojištění na českém pojistném trhu je zvyšování jeho podílu na celkovém předepsaném pojistném (v roce 1998 tento podíl činil $27 \%$, v roce 2003 39,2 \%) a rostoucí výše technických rezerv životního pojištění (v současné době dosahuje výše těchto rezerv $5 \%$ HDP). Rozvoj životního pojištění je spojen s dostatečným počtem pojistitelů, kteří se životním pojištěním zabývají (v současné době 19) a podoba produktů životního pojištění se postupně přiblížila podobě produktů provozovaných $\mathrm{v}$ zahraničí. Rychlý růst životního pojištění $\mathrm{v}$ posledním období byl vyvolán především zavedením daňového zvýhodnění u životního pojištění (daňové zvýhodnění se v současné době týká 2,5 mil. smluv životního pojištění z celkem 6 milionů pojistných smluv). Ovšem je třeba si uvědomit, že existuje poměrně rozsáhlý prostor pro další rozvoj životního pojištění: existuje rozdíl v postavení životního pojištění na celkovém pojistném trhu v České republice a v Evropské unii, nebot’ v Evropské unii činí v současné době podíl předepsaného pojistného v životním pojištění na celkovém předepsaném pojistném více než $60 \%$, dále existuje prostor v růstu velikosti pojistných částek a tím i pojistného (v zahraničí se považuje za optimální výše pojistné částky odpovídající dvojnásobku ročního platu).

V obecném uplatnění životního pojištění lze pozorovat změny v pojetí významu životního pojištění. Ve vyspělých zemích je v současné době přikládán význam životnímu pojištění zejména $\mathrm{z}$ pohledu krytí potřeb ve stáří. $\mathrm{Z}$ tohoto pohledu nehraje $\mathrm{v}$ podmínkách České republiky životní pojištění tak rozsáhlou roli. Vyplývá to z toho, že se lidé stále ještě spoléhají ve svých úvahách o krytí potřeb ve stáří na státní sociální důchodové pojištění, které se nachází ve značných problémech a míru krytí potřeb lidí ve stáříbude muset do budoucna omezit. Dále není dostatečně tato role životního pojištění v povědomí a na rozdíl od řady států Evropské unie lidé při spoření preferují jiné spořicí nástroje před životním pojištěním. 
Graf č. 7: Rozložení úspor obyvatelstva ve vybraných evropských zemích (v \%)

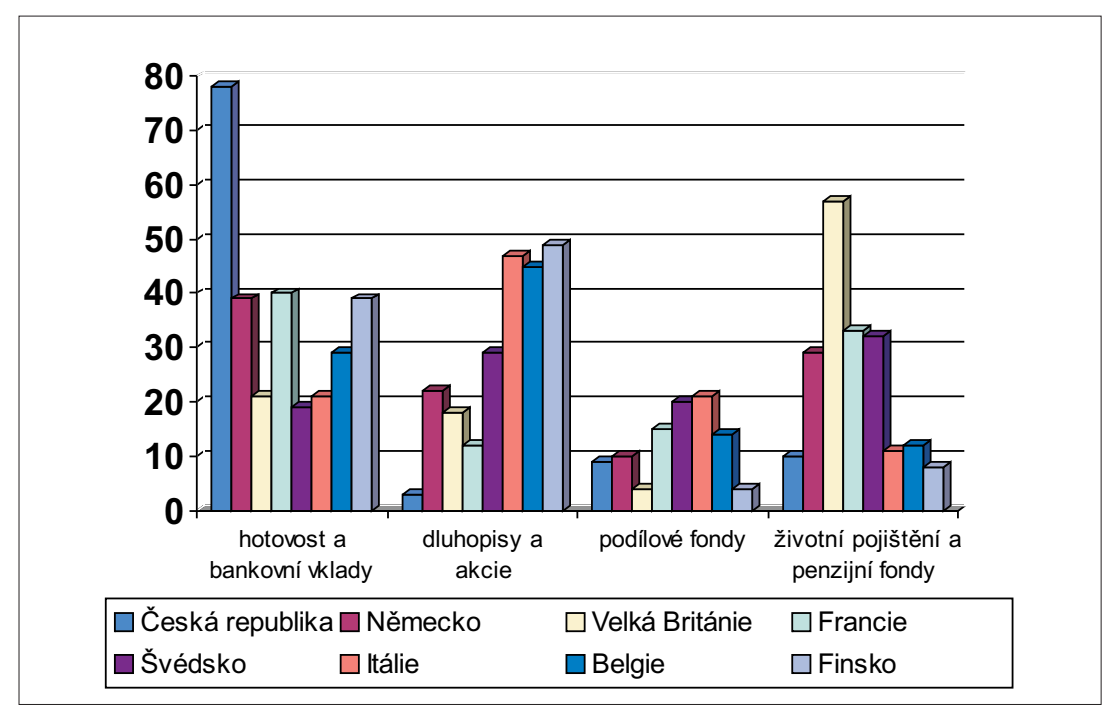

Pramen: Voborský, R.: Postavení životního pojištění v rámci finančních služeb v ČR, Pojistný obzor č. 3/2004.

Tab. č. 4: Vývoj ve struktuře úspor obyvatelstva v ČR - podíl jednotlivých druhů úspor v \%

\begin{tabular}{|l|r|r|r|r|}
\hline & $\mathbf{1 9 9 9}$ & $\mathbf{2 0 0 0}$ & $\mathbf{2 0 0 1}$ & $\mathbf{2 0 0 2}$ \\
\hline Vklady u bank & 73,7 & 70,1 & 69,0 & 63,1 \\
\hline Stavební spoření & 10,1 & 11,1 & 12,4 & 15,4 \\
\hline Penzijní připojištění & 3,4 & 4,0 & 4,7 & 5,1 \\
\hline Podílové fondy & 4,6 & 6,1 & 4,8 & 6,8 \\
\hline Životní pojištění & 8,3 & 8,6 & 9,1 & 9,6 \\
\hline
\end{tabular}

Pramen: Voborský, R.: Postavení životního pojištění v rámci finančních služeb v ČR, Pojistný obzor č. 3/2004.

Ve struktuře neživotního pojištění v podmínkách českého pojistného trhu činí významný podíl pojištění vozidel, zejména pojištění odpovědnosti za škody z provozu vozidel (viz tabulka č. 5). Ve srovnání s pojistnými trhy v rámci Evropské unie je právě podíl pojištění vozidel výrazně vyšší, nebotv p průměru v zemích Evropské unie činí podíl předepsaného pojistného $\mathrm{v}$ pojištění vozidel na předepsaném pojistném v neživotním pojištění okolo $34 \%$. Na druhé straně pro některá další odvětví neživotního pojištění je typický v podmínkách českého pojistného trhu nižší podíl ve srovnání s Evropskou unií. Jde zejména o pojištění nemoci a úrazu, pojištění přeprav a pojištění právní ochrany.

K určitým změnám by mohlo dojít v souvislosti se vstupem České republiky do Evropské unie v rámci cestovního pojištění, především jeho dosud nejvýznamnější části, tedy pojištění léčebných výloh. Na jednu stranu přistoupení k Evropské unii znamená omezení potřeby tohoto pojištění $\mathrm{v}$ důsledku platnosti mezinárodních úmluv o poskytování zdravotní péče v rámci zemí Evropské unie. Na straně druhé poměrně značné uplatnění spoluúčastí na financování zdravotní péče pacienta v jednotlivých zemích, nehrazení některých, například repatriačních nákladů v rámci veřejného zdravotního pojištění, někdy komplikované praktické uplatnění mezistátních dohod při ošetření privátními lékaři ukazuje na nadále existující potřebnost pojištění léčebných výloh. Nehledě na skutečnost, že cestovní 
pojištění není jen pojištění léčebných výloh, ale řada druhů pojištění, která kryjí jiná než zdravotní rizika při cestování.

Tab. č. 5: Pojiššení odpovědnosti za škody z provozu vozidla - podíl na předepsaném pojistném v neživotním pojištění v \%

\begin{tabular}{|l|c|c|c|c|}
\hline & $\mathbf{2 0 0 0}$ & $\mathbf{2 0 0 1}$ & $\mathbf{2 0 0 2}$ & $\mathbf{2 0 0 3}$ \\
\hline Pojištění odpovědnosti za škody z provozu vozidel & 29,9 & 30,7 & 31,7 & 31,0 \\
\hline Havarijní pojištění pozemních vozidel & 22,3 & 20,6 & 21,1 & 20,8 \\
\hline Celkem pojištění vozidel & 51,2 & 51,3 & 52,8 & 50,8 \\
\hline
\end{tabular}

Pramen: Výroční zprávy ČAP.

V rámci neživotního pojištění se dá předpokládat změna struktury ve prospěch pojištění osob, tzv. úrazového pojištění a nemocenského pojištění, a také ve prospěch pojištění odpovědnosti. Pojištění osob by mělo zvýšit svůj význam v souvislosti s tendencemi zvyšování odpovědnosti jednotlivců za svůj vlastní život, tedy menší rolí sociálních dávek při krytí daných potřeb. Rozvoj pojištění odpovědnosti za škody by se měl projevit jak ve zvyšování počtu smluv odpovědnostního pojištění, tak v přizpưsobování se legislativních podmínek situaci v Evropské unii, např́íklad v prohlubování spotřební odpovědnosti (pojištění odpovědnosti za výrobek), využití komerčního pojištění pro krytí ekologických škod, prohlubování odpovědnosti při provozování různých specifických činností.

V souvislosti se vstupem do Evropské unie dochází $\mathrm{k}$ určitému přizpůsobování podmínek na českém pojistném trhu v oblasti zemědělského pojištění, kdy se uskutečňují reálné úvahy o podpoře zemědělského pojištění ze strany státu prostřednictvím dotací k cenám zemědělského pojištění.

\section{Možné změny podoby pojistného trhu po vstupu do Evropské unie}

Nižší pojištěnost než v řadě evropských zemí v některých segmentech českého pojistného trhu může vyvolat zájem ze strany zahraničních pojištoven o vstup na český pojistný trh. Ovšem výraznější změny v působení zahraničních pojistitelů na českém pojistném trhu se nepředpokládají s ohledem na skutečnost, že významné evropské pojištovny již na našem trhu působí řadu let (vstupovaly na český pojistný trh již v průběhu devadesátých let). Významnější změny se očekávají $\mathrm{v}$ této souvislosti $\mathrm{v}$ oblasti pojištění podnikatelů než v rámci pojištění fyzických osob. Nadnárodní podnikatelské subjekty budou zřejmě využívat ve větší miŕre pojištovánísvých rizik prostřednictvím jednoho pojistitele v rámci Evropské unie. Z oblasti pojištění obyvatelstva by se mohly objevovat snahy zahraničních pojištoven prosazovat se na českém pojistném trhu v souvislosti s nabídkou nových produktů z oblasti životního pojištění a navazujících pojistných produktů. Přitom nelze opomenout skutečnost, že v rámci pojištovnictví existuje obvyklá provázanost sjednání pojištění s místem sídla pojištěného.

Skutečností, která může ovlivnit pojištovnictvív podmínkách České republiky, je vyšší úroveň ochrany spotřebitele v zemích Evropské unie. Proto lze očekávat dopady v důsledku změn v pojetí a uplatňování ochrany spotřebitele v praxi v podmínkách ČR. Jednak př́mo v oblasti ochrany spotřebitele jako klienta pojištoven, což se již projevuje v nové úpravě pojistné smlouvy, v metodách regulace pojištoven a v novém přístupu k úpravě činnosti pojištovacích zprostředkovatelů. Dále se otázky zvyšování ochrany spotřebitele projeví větším uplatněním některých pojistných produktů, které navazují na zvyšování úrovně 
ochrany spotřebitele, zejména v oblasti pojištění odpovědnosti za škody, případně pojištění právní ochrany.

Oblastmi komerčního pojištění, u kterých se předpokládá další postupný rozvoj po přistoupení k jednotnému evropskému pojištovacímu trhu, je jednak životní pojištění, dále nemocenské, zdravotní a úrazové pojištění. Tato odvětví by měla reagovat na v budoucím období změněné podmínky v sociálním pojištění.

Změny cen v rámci českého pojištovnictvív důsledku vstupu České republiky do Evropské unie se nepředpokládají, kromě pojištění odpovědnosti za škody z provozu vozidel, okamžitě, ale spíše postupně, v návaznosti na celkový mzdový a cenový vývoj.

\section{Literatura}

1. DUCHÁČKOVÁ, E.: Principy pojištění a pojišrtovnictví. Ekopress, Praha 2003.

2. DAŇHEL, J.: Kapitoly z pojistné teorie. Oeconomica, Praha 2002.

3. VÝBORSKÝ, R.: Postavení životního pojištěnív rámci finančních služeb. Pojistný obzor, 3/2004.

4. Výsledky členských pojištoven ČAP, Pojistný obzor, 4/2004.

5. ŠKOPOVÁ, V.: K novému zákonu o pojistné smlouvě. Pojistný obzor, 4/2004.

6. DUCHÁČKOVÁ, E.: Světový pojistný trh v roce 2002. Pojistný obzor, 4/2004.

7. World insurance in 2002: hign premium growth in non-life insurance, Sigma No. 8/2003, Economics Research \& Consulting, Swiss Reinsurance Company, Zürich.

8. Výroční zprávy ČAP, 2002, 2000. 